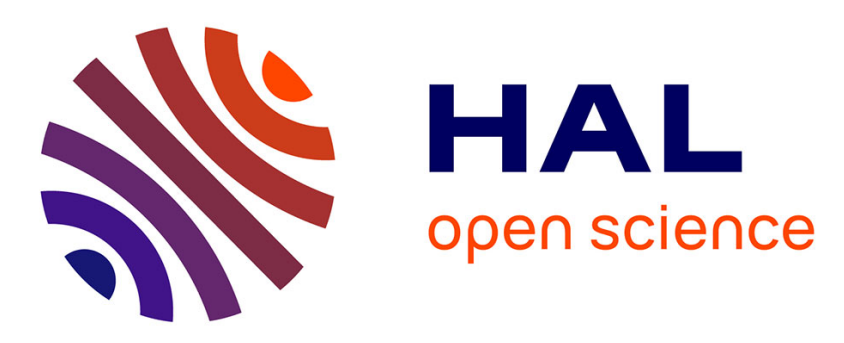

\title{
The Acceptance of Motion Detection Devices by the Elderly
}

Marcelo Brites-Pereira, Maria João Almeida, António J. Osório

\section{To cite this version:}

Marcelo Brites-Pereira, Maria João Almeida, António J. Osório. The Acceptance of Motion Detection Devices by the Elderly. 11th IFIP World Conference on Computers in Education (WCCE), Jul 2017, Dublin, Ireland. pp.189-195, 10.1007/978-3-319-74310-3_21 . hal-01762891

\section{HAL Id: hal-01762891 \\ https://hal.inria.fr/hal-01762891}

Submitted on 10 Apr 2018

HAL is a multi-disciplinary open access archive for the deposit and dissemination of scientific research documents, whether they are published or not. The documents may come from teaching and research institutions in France or abroad, or from public or private research centers.
L'archive ouverte pluridisciplinaire HAL, est destinée au dépôt et à la diffusion de documents scientifiques de niveau recherche, publiés ou non, émanant des établissements d'enseignement et de recherche français ou étrangers, des laboratoires publics ou privés.

\section{(c)(1)}

Distributed under a Creative Commons Attribution| 4.0 International License 


\title{
The Acceptance of Motion Detection Devices by the Elderly
}

\author{
Marcelo Brites-Pereira ${ }^{1 \text { [0000-0002-6826-5465] }}$ Maria João Almeida ${ }^{\text {[0000-0003-4061-8924] }}$ \\ António J. Osório ${ }^{1}$ [0000-0002-9931-1962] \\ ${ }^{1}$ University of Minho, Gualtar Campus, Portugal \\ ${ }^{2}$ University of Coimbra, Estádio Universitário, St ${ }^{\mathrm{a}}$ Clara, Portugal \\ marcelobritespereira@gmail.com
}

\begin{abstract}
Considering the importance of ageing well, the aim of this study is to understand how the elderly learn to use digital technologies of movement detection. With the study of motion detection devices, we intend to contribute to the development of knowledge regarding care and the occupational therapy needs of the elderly in the context of their quality of life.
\end{abstract}

Keywords: Elderly, Kinect, Nintendo Wii, Leap motion.

\section{Introduction}

According to data revealed by the WHO, from 2001 to 2013 the number of elderly people per 100 young people grew from 102 to 136 [1].

The European Union has made considerable policy and financial efforts on research and action focused on active aging, launching initiatives and programs that have contributed to the development of social and health infrastructures and services, which help to respond nationally and regionally to some of the challenges of aging in today's society.

An example of these efforts is the Manifesto for European Friendship of the Elderly until 2020, launched in 2012 as part of the European Year for Active Aging and Solidarity between Generations. The manifesto has 10 proposals, of which Information and Communication Technology (ICT) learning and digital inclusion items should be highlighted. Faced with these facts, it is imperative that different modes of contact between the elderly and ICT are found, ways that promote physical activity and at the same time, allow real digital inclusion and social sharing. In fact, the practice of physical exercise decreases the risk of developing cardio-respiratory diseases, chronic-degenerative diseases, diabetes and dementia and increases better blood circulation, levels of social interaction, physical performance, happiness and prevents early death [2-5].

Therefore, affordable motion detection devices such as Kinect, Leap Motion or Nintendo Wii, can mediate physical activity appropriate for the needs of the elderly. Based on this notion, we considered it relevant to research and study, in detail, the characteristics of the process of using these technologies in activities that can be offered to the elderly population. 


\section{Old, Elderly, or Senior?}

There is a range of terminologies to characterize citizens over 65 years of age. For some experts, seniors, or senior citizens is the right terminology, whilst others prefer the term "seniors". The truth is that, according to José H. Barros de Oliveira (2005) the way we address the aged is irrelevant, since understanding and helping them is most important [6]. The author also states that "it is not worth using euphemisms to refer to the elderly." For him, the terminology 'old' may not be deprecatory, and can be considered affectionate when, for example the term, 'my old man' is used. However, the author acknowledges that the term 'old' has a derogatory sense in society and therefore assumes that, in a generic way, the socially accepted term is 'elderly' [6].

Therefore, elderly, according to the World Health Organization (WHO), is anyone that has reached the age of 65 . However, the same organization reports that, in developing or underdeveloped countries, the term "elderly" could be referred to an individual aged 60 or less, since the average longevity in these countries is lower when compared with developed countries.

\section{Physical activity using motion detection devices}

There are animal and human studies that suggest that physical activity, or its absence, has a strong influence on brain functions such as memory, cognition, learning, and the pathological counterpart of memory, such as cognitive decline in aging. These studies have increased the number of biological recognition mechanisms that attest the benefits of physical activity to brain health [5].

We know that about 30 years ago, the first studies regarding the interest of learning ICT by the elderly showed a negative reaction on the part of the participants. More recently, however, Dyck \& Smither, (1994) found a more positive reaction in the elderly over 55 [7].

Nowadays, it is known that the cause of the majority of the elderly that react negatively to the use of ICT is related to myths, like Wandke, Wandke, Sengpiel, \& Sönksen, (2012) who state that age does not constitute a barrier in learning [8].

Although memory does tend to lose its plasticity, the elderly tend to have a better memory of past events than working memory - also known as short-term memory which may have an effect in learning about the use of new technologies. Therefore, based on this, it cannot be said that the elderly cannot learn, since many studies have shown that they can by stimulating short-term and long-term memory [9-11].

Using exergames with the elderly does not only imply brain functions, but also implies motivation and user acceptability. There are a number of theories that have been used to gauge technology acceptability. As an example, we have the selfefficacy theory, which demonstrates the power of believing that one can, the unified theory of acceptance and use of technology or the technology acceptance models, that are widely used among researchers to measure, anticipate and explain the user's actions [12-15].

Brox \& Hernandez, (2011) also exposed some strategies to persuade and motivate the elderly for change using exergames as a strategy for active healthy aging [16]. To 
motivate users, they also recommend "making an attractive and friendly user interface". It is also important not to disturb the users while they are playing the games, but providing them with information in appropriate and opportune moments. Finally, the authors suggest using "social influence" to bring about behavior changes. Based on this, we would like to add the importance of playing exergames in a community setting, since studies suggest that people exercise more efficiently when this is done in the company of others [17].

Brox \& Hernandez, (2011) also state that "exergames have the potential to motivate the elderly to become more physically active, since it is perceived as fun to play" and believing in that, has led us to want to know more about the use of these devices among elderly. We also want to develop this research using 3 different devices to know more about the acceptability of these devices among the elderly and not discoloring social factors [16].

Given the advances in technology, Microsoft Kinect Xbox 360 has been developing new technology in which players can control the game without the need of hand controls, using only their own body, which is detected through their body temperature. This technology has been tested in institutionalized elderly people with some form of disability, since they may not be able to maintain and hold controllers due to the lack of muscular strength.

Leap Motion and Nintendo Wii with Wii Remote require mobility of the upper limbs, which does not exclude people with disabilities from physical activity. A study made by Chen, Huang, \& Chiang, (2012) concluded that games have great potentials as a health promotion tool for the elderly with disabilities, since they stimulate social functions which are especially important for the elderly, because they can strengthen their general moods and decrease levels of depression and stress [18].

Playing also increases visual and fine motor abilities, as well as attention skills. Tests have showed that games have a positive influence in short-term memory and selective attention and motivation for the elderly [19-21]. However, there is a lack of studies focused on the acceptability and suitability of these technologies for the elderly.

\section{Economic and demography}

Sedentarism, along with ageing, promotes the appearance of cardiorespiratory diseases, diabetes, neurodegenerative diseases and bone and muscle weakness, therefore quickening the aging process.

The adoption of the practice of physical activity by the elderly, often inactive and sedentary, improves their quality of life minimizing health costs and benefiting from greater longevity [22, 23].

Previous investigations have shown how technologies, like a computer, can help the elderly in socio-economic inclusion [24].

Our focus is not on the financial or economic problem, however it is important that countries are able to save money related to the care of the elderly as it is common that countries spend a great deal on care and treatment. Therefore, we focus on the prevention of aged related illnesses through education and physical exercise. Education is an act involving the integration and transformation of the individual, so 
through education, countries can save money and provide therapy against socioeconomic "exclusion and obsolescence". For this reason, we will attempt to develop a research about how the elderly can use and learn how to use motion detection technologies [25] as our society today is getting older, faster, and as a result, there is a strong need to find a solution to keeping the elderly active and healthy.

One possible solution involves exercising with the aid of video games (exergames) which encourage the elderly to remain active even when living in full-time care environments. In this context, it is important to provide technology which is easy to set up in order to relieve nursing staff of added work and reduce access barriers.” [26] By keeping the elderly active, it is also possible to provide an investment in prevention, social comfort and integration.

\section{Problem and objectives}

According to Lees \& Frank, (2004) [4], a sedentary lifestyle is a problem that leads to premature death. Therefore, this project intends to investigate the use of motion detecting devices (Kinect, Leap Motion, Wii Remote) in the process of promoting physical activity for institutionalized elderly citizens (or in the context of active aging). In order to understand how to properly use such technologies, it is important to address this problem, as aging is a natural process that must be taken seriously. The dignity and quality of life of the elderly should be enhanced and enhanced with all the existing resources.

According to Cassola, Morgado, de Carvalho, Paredes, \& Fonseca, (2014) and Parra, (2014), there are still some limitations in digital motion detection technologies, which means that there is considerable room for improvement and research in this area $[27,28]$.

Thus, as a result of social and personal experience in different institutions, we found that sedentarism is, in some cases, an institutional problem, since the elderly, when institutionalized, become less active and in the short/medium term, more dependent on third parties for care and assistance not only in movement, but also in simple tasks such as feeding themselves. This sedentary lifestyle can, and should be changed. Greater autonomy for the elderly means a better quality of life, greater selfesteem and fewer depression related symptoms. Also, human and financial resources could be decreased as the number of bedridden individuals requiring more specialized care and attention would be reduced.

Therefore, there is a need to encourage the elderly population to participate in mediated physical exercise, taking into account their physical limitations, age and interaction. In order to better understand how to use the technologies of motion detection devices for the elderly to enjoy and benefit from active aging, bringing benefits in the treatment and prevention of possible degenerative diseases, we intend to:

- Research the acceptance of digital spaces by the elderly in day-care centers;

- Experiment with 3 motion-detecting devices in active aging activities; 
- Analyze, through the observation and capture of video images, the mobility of the elderly in the interaction with the various devices for detecting movements;

- Analyze, through recorded interviews, the interest of the elderly population in ICT education;

\section{Methodology}

This investigation will start with a theoretical review of the literature, in order to understand and describe the state of the art in relation to elderly sedentarism. In second phase, there will be a practical intervention carried out through collaborative activities with institutions for the elderly for the implementation of the study.

To enable this interactivity, motion detection devices - Kinect, Wii Remote, Leap Motion - and exergames to enable physical activities in a creative and multidimensional way will be used.

Before beginning the practical session with the motion detecting devices, we will apply an OARS (Older Americans Resources and Services) questionnaire, which will permit the measurement of the degree of incapacity of every elderly person. The questionnaire allows the generation of functional assessment scales, divided by 5 large groups, using the Likert Scale score system. The final sum of the selected scores generates the accumulated functional disability score of each elderly person.

Each practical session will last 60 minutes in which every elderly individual will have 10 minutes for initial warm-up and, after that, 45-50 minutes of exercise during 12 weeks, three times per week, on alternate days, for 36 sessions.

The creation of videos in loco will constitute an innovation in the research method bringing benefits, and providing an important contribution to a visual anthropological investigation.

In addition, during the practice sessions, data will be recorded by direct observation and videotaped during the process of contacting the various digital motion detection devices.

For data analysis, we will use software Nvivo®, and the audio interviews will be transcribed. The notes taken during the direct observation will be crossed and the answers provided by the applied questionnaires will be statistically analyzed.

To preserve identity and privacy of those involved, the data will only be collected after the consent and authorization of the institution that will host the investigation and by the elderly directly involved in the research is provided.

At present, we are currently waiting for a favorable opinion from the Portuguese Commission for Ethics for Clinical Research (CEIC) and Portuguese National Commission for Data Protection (CNPD).

\section{Expected outcomes}

From this analysis, we hope to learn how digital motion detection technologies and games can be readily accepted by the majority of the elderly in order to contribute positively to their active aging. 


\section{Acknowledgments}

This research is being developed within the PhD Program: Technology Enhanced Learning and Societal Challenges, funded by Fundação para a Ciência e Tecnologia, FCT I. P., Portugal, under contract PD/BD/128348/2017.

\section{References}

1. INE, I.N. de E.: População residente em Portugal com tendência para diminuição e envelhecimento. (2014).

2. Bherer, L., Erickson, K.I., Liu-Ambrose, T.: A review of the effects of physical activity and exercise on cognitive and brain functions in older adults. J. Aging Res. 2013, 8 (2013).

3. Hsiao, K., Rashvand, H.F.: Data modeling mobile augmented reality: integrated mind and body rehabilitation. Multimed. Tools Appl. 1-18 (2013).

4. Lees, S.J., Frank, W.: Sedentary Death Syndrome Introduction : Inactivity is an Actual Cause of Death. Aids. 29, 447-460 (2004).

5. Lista, I., Sorrentino, G.: Biological mechanisms of physical activity in preventing cognitive decline. Cell. Mol. Neurobiol. 30, 493-503 (2010).

6. José H. Barros de Oliveira: Psicologia do Envelhecimento e do Idoso. (2005).

7. Dyck, J.L., Smither, J.A.-A.: Age Differences in Computer Anxiety: The Role of Computer Experience, Gender and Education. J. Educ. Comput. Res. 10, 238-248 (1994).

8. Wandke, H., Sengpiel, M., Sönksen, M.: Myths About Older People’s Use of Information and Communication Technology. Gerontology. 58, 564-570 (2012).

9. David M. (Mike) Moore, John K. Burton, R.J.M.: Multiple-channel communication: the theoretical and research foundations of multimedia. 979-1005 (1996).

10. Willis, S.: Methodological issues in behavioral intervention research with elderly. Em: V. Bengtson \& K. W. Schaie (ed.) Handbook of Psychology of Aging. NY: Academic Press. , NY (2001).

11. Schmiedek, F., Lövdén, M., Lindenberger, U.: Hundred Days of Cognitive Training Enhance Broad Cognitive Abilities in Adulthood: Findings from the COGITO Study. Front. Aging Neurosci. 2, (2010).

12. Nawaz, A., Skjæret, N., Helbostad, J.L., Vereijken, B., Boulton, E., Svanaes, D., Skjaeret, N., Helbostad, J.L., Vereijken, B., Boulton, E., Svanaes, D.: Usability and acceptability of balance exergames in older adults: A scoping review. Health Informatics J. 22, 911-931 (2015).

13. Viswanath Venkatesh , Michael G . Morris, Gordon B . Davis, F.D.. D., Venkatesh, V., Morris, M.G., Davis, G.B., Davis, F.D.: User acceptance of information technology: Toward a unified view. MIS Q. 27, 425-478 (2003).

14. Davis, F.D.: Perceived Usefulness , Perceived Ease Of Use, And User Acceptance. MIS Q. 13, 319-339 (1989).

15. Maddux, J.E.: Self-Efficacy Theory. Em: Maddux, J.E. (ed.) Self-Efficacy, Adaptation, and Adjustment: Theory, Research, and Application. pp. 3-33. Springer US, Boston, MA (1995).

16. Brox, E., Hernandez, J.E.G.: Exergames for elderly: Social exergames to persuade seniors to increase physical activity. Em: 2011 5th International Conference on Pervasive Computing Technologies for Healthcare (PervasiveHealth) and Workshops. pp. 546-549 (2011). 
17. Mueller, F.F., O’Brien, S., Thorogood, A.: Jogging over a distance: supporting a «jogging together» experience although being apart. Chi Ea. 1989-1994 (2007).

18. Chen, S.T., Huang, Y.G.L., Chiang, I.T.: Using somatosensory video games to promote quality of life for the elderly with disabilities. Proc. 2012 4th IEEE Int. Conf. Digit. Game Intell. Toy Enhanc. Learn. Digit. 2012. 258-262 (2012).

19. Green, C.S., Bavelier, D.: Action video game modifies visual selective attention. 423, 534-537 (2003).

20. Gamberini, L., Barresi, G., Majer, A., Scarpetta, F.: A game a day keeps the doctor away: A short review of computer games in mental healthcare. 127-145 (2008).

21. Ijsselsteijn, W., Nap, H.H., de Kort, Y., Poels, K.: Digital game design for elderly users. Em: Proceedings of the 2007 conference on Future Play - Future Play '07. p. 17. ACM Press, New York, New York, USA (2007).

22. Mazo, G.Z., Mota, J., Gonçalves, L.H.T., Matos, M.G., Carvalho, J.: Actividade física e qualidade de vida de mulheres idosas da cidade de Florianópolis , Brasil. Rev. Port. Ciências do Desporto. 8, 414-423 (2008).

23. Giovana Zarpellon Mazo, Jorge A. Pinto da Silva Mota, L.H.T.G.: Atividade física e qualidade de vida de mulheres idosas, (2005).

24. Stewart, J., Bleumers, L., Looy, J. Van, Mariën, I., All, A.: The Potential of Digital Games for Empowerment and Social Inclusion of Groups at Risk of Social and Economic Exclusion: Evidence and Opportunity for Policy European Commission. , Luxemburg (2013).

25. Zarifis, G.K., Gravani, M.: Challenging the 'European Area of Lifelong Learning': a critical response after a decade of ongoing adjustments. (2012).

26. Gerling, K.M., Schulte, F.P., Masuch, M.: Designing and evaluating digital games for frail elderly persons. Em: Proceedings of the 8th International Conference on Advances in Computer Entertainment Technology - ACE '11. p. 1. ACM Press, New York, New York, USA (2011).

27. Cassola, F., Morgado, L., de Carvalho, F., Paredes, H., Fonseca, B.: Online-Gym: A 3D Virtual Gymnasium Using Kinect Interaction. Procedia Technol. 13, 130-138 (2014).

28. Parra, C.: Information Technology for Active Ageing: A Review of Theory and Practice. Found. Trends ${ }^{\circledR}$ Human-Computer Interact. 7, 351-444 (2014). 